\title{
Belarus in the Congressional Record 1873-1994
}

\author{
BY \\ TATSIANA KULAKEVICH
}

Many authors have long recognised that migrants have an impact on employment, economic development, demographic trends, as well as foreign policy. The role of migrants can be both constructive, by providing ties and promoting democratic values between their home and host societies, or destructive, by serving as a source of instability in their homeland (Shain 2003). Large masses of people moving from one place to another can help societies better understand each other. Migrants can campaign to democratize authoritarian homeland regimes or serve as a force in the global economy by encouraging or discouraging global investment (Leblang 2010). Also, migrant communities of stateless nations historically played a major part in the struggle for political independence in their countries of origin (Shain 1994).

This paper looks at evolving U.S. policy towards Belarus (1873-1994) translated through a domestic, intervening variable. Specifically, it focuses on the role of migrants contributing to the development of American government policy towards Belarus over more than a century.

The role of the Belarusian diaspora in influencing political attitudes in general and specifically its significance in U.S. policy towards Belarus has not received much coverage. P. Rudling, for example, suggests that, unlike its neighbors, at the beginning of the 20th century Belarus lacked a diaspora of any influence (Rudling 2012). O. Koval, in turn, indicates that individual Belarusian immigrants often joined the activities of Ukrainian, Polish, and Russian diasporas to promulgate their ideas. In any case, the political activity of Belarusian communities in the United States was not well visible from 1918 and 1939 (Koval 2010). V. Kipel in his work about Belarusian-Americans expresses the view that the immigrants were mostly preoccupied with establishing their proper ethnic identity (Kipel 1993, 2017).

Interconnections between immigrants' countries of origin and destination, including immigrants' role in defining the relationships between their host country and the country of origin, has been important for Belarus under the Soviet 
rule. This paper argues that the activity of the post-World War II immigrants from the early 1950s to the collapse of the Soviet Union, drawing attention to the Belarusian Soviet Socialist Republic (BSSR) as a colonial region under the Communist oppression, served as an intervening variable shifting attention of the American government to Belarus from being considered a voiceless territory under the Russian influence to a separate country suffering from Communism and deserving the right for national independence.

This paper examines American policy towards Belarus through the analysis of the Congressional Record, ${ }^{1}$ published proceedings of activities of the United States Congress. Covering the period from 1873, when the Congressional Record was first published (the 43rd Congress), till 1994 (the 103rd Congress), soon after the collapse of the Soviet Union when Belarus became an independent state, this article observes the evolution of the American government's interest towards Belarus and examines the role of Belarusian diaspora in the United States on the distribution of that attention.

The rest of this study is organised as follows. First, the Congressional Record reveals how the United States perceived Belarus at the end of the 19th and the beginning of the 20th centuries and the reasons for the lack of interest to Belarus as a separate state. Then, the paper discusses the role and activities of migrants during the interwar and the post-World War II period. After that, the article shows the change in attitude of American politicians towards Belarus as a state deserving closer attention. Then, the penultimate section provides an overview of Belarus in the Congressional Record after the collapse of the Soviet Union. The final section offers suggestions for future research.

\section{First Remarks about Belarus}

At the time when the Congressional Record started its publications in 1873, the territory of present Belarus comprised a part of the Russian Empire designated as Northwestern territory. Russian policy sought complete Russification of the region. The first mention of the territories comprising present day Belarus in the Congressional Record appears in 1882 with the mentioning of separate gubernias

\footnotetext{
The Congressional Record is the official record of the proceedings and debates of the United States Congress. First published in 1873, the Congressional Record is the fourth series of publications, recording proceedings, roll calls, debates, and other records. Before 1873, it was published in three forms and under three different titles: The Annals of Congress of the United States (1789-1824), the Register of Debates in Congress (1824 - 1837), and the Congressional Globe (1833 - 1873). The Congressional Record consists of four sections: the proceedings of the House, the proceedings of the Senate, the Extensions of Remarks, and the Daily Digest of activity in the Congress. Appendixes appear in most volumes. It is published daily when either or both Houses of Congress are in session. Indexes are issued every two weeks. At the end of a session of Congress, the daily editions are compiled in volumes creating the permanent edition.
} 
(territorial subdivisions of Russian imperial government) and places in connection with the persecution of Jews ${ }^{2}$ in Russian Empire: "These outbreaks are not local. Whether at Minsk, ${ }^{3}$ where eight thousand Jews lost their all, or at Koretz, where thirty Jews were burned" (Congressional Record 1882, p. 653).

Almost all immigrants from the present day Belarusian territories to the U.S. at that time were poor, uneducated and nationally unconscious peasants. They could neither establish national organizations nor advocate for the national independence of their homeland. Depending on their religious beliefs, they mostly joined Russian, Ukrainian or Polish communities (Hardzijenka 2009). In his book Belarusians in the United States, Kipel claims that it is almost impossible to decipher the exact number of Belarusian migrants at the end of the 19th century and the beginning of the 20th century, because the documents of the immigration services and the Census Bureau of the United States did not have exact information about nationalities of new American citizens at that time. As Kipel notes, nationality was assigned by the 'state rather than ethnicity' (Kipel 1993). A. Tsihamirau, however, suggests that about 450,000-500,000 ethnic Belarusians came to live to the United States before 1914 (Hardzijenka 2009).

The presence of Belarus as a separate political entity does not appear in the Congressional Record until 1918 when it surfaces under the name of White Russia $^{4}$ in the document pertaining to Lithuania, Livonia and Estonia. One of the statements reads: "The Lithuanians were never barring the road to independence to the oppressed neighbouring peoples and nations; they have always advocated the liberation of White Russia, Poland, Ukraine, Estonia, Finland, Armenia, the various Slav races and so forth" (Congressional Record 1918, p. 9624). In May 1920, the Congressional Record mentions 'the petition of former citizens of White Russia, Ukrainia, and Lithuania at a meeting at St. Louis, [Missouri], favoring the freedom and self-determination of said countries; to the Committee on Foreign Affairs' (Congressional Record 1920, p. 7556).

Belarus also appears in connection with the devastation of Polish and Belarusian territories at the time of the World War I, when 'the Germans had driven the Russian Army back through Poland into White Russia, so-called, beyond Brest-Litovsk' (Congressional Record 1932, p. 12536). At that time, the U.S. was discussing recognition of the Soviet Union.

\footnotetext{
2 At the end of the 19th century, a series of persecutions against Jews took place in the Russian Empire. The persecutions took placed within a complex context of interethnic relations and popular violence in an Empire which was undergoing rapid social and political change (Klier 2002).

3 Minsk is the capital of Belarus.

4 Belarus is known as 'White Russia' due to the literal translation of the part 'Bela' or 'Byelo' as white.
} 


\section{Belarus during the Interwar Period}

Throughout the 1930s, relations between the U.S and the Soviet Union were cool, despite American diplomatic recognition of the Soviet Union in 1933. The countries did not have either major areas of agreement or pressing conflicts of interest. The U.S. Great Depression and Hitler's actions on the international arena together with low immigration activity before and during the war resulted in Belarus being mainly identified by the American government in connection with other states and events and being only sporadically mentioned in the Congressional Record.

The Belarusian immigrants who came to the U.S. during the post World War I years were few. According to Kipel (2017), those who did consisted mainly of political immigrants. Among them came the first Prime-Minister of the Belarusian People's Republic (BNR), ${ }^{5}$ Jazep Varonka and an activist, Janka Čarapuk. Together with previously arrived other representatives of Belarusian-American diaspora, they made a somewhat successful effort to consolidate Belarusians by organizing the Belarusian-American National Association in Chicago, which remained the only Belarusian centre in the United States for the next 20 years (Hardzijenka 2009).

The concept of Belarus as a political unit became prevalent at the outbreak of World War II. On October 8, 1939, the Prime Minister of the British Empire during the first World War, David Lloyd George, looked to the U.S. to convene a peace-solution parley with Hitler in connection with the annexation of Polish state areas by the Soviet Union, whereby the areas would become a part of an existing Soviet republic. David Lloyd George identified Belarus as a separate state by saying that "it would be a mistake to compare the conditions of the present war with those of the last... You cannot put forward the same demand with regard to Poland. It would be a challenge to Russia, who has annexed the White Russian and Ukrainian provinces of Poland which are not Polish by race, language, or religion" (Congressional Record 1939, p. 204).

Germany invaded the Soviet Union on June 22, 1941, and for most of the next four years, Nazi armies left a trail of blood and terror in the Soviet territories they occupied. The Congressional Record reports rather sporadically about these events. On occasion, it also mentions occupied Belarusian territories. For example, it notes that "over 25,000 Jews in Brest-Litovsk, Pinsk, Wladimir-Wolynsk, and Vitebsk have already suffered execution at the hands of the invaders... In Minsk, Gomel, Berdichev, Zhitomir, Mohilev, all densely Jewish-populated areas, Jews

5 The Belarusian People's Republic (Bielaruskaya Narodnaja Respublika, BNR) was an attempt to create Belarusian independence in 1918. It was proclaimed on March 25, 1918 and replaced by the Byelorussian Soviet Socialist Republic (BSSR) on January 1, 1919. 
were evicted from their homes to make room for German soldiers" (Congressional Record 1942, p. 2849). The Congressional Record mentions Minsk among the cities destroyed by the Nazis (Congressional Record 1943, p. 2228).

\section{Belarus after World War II}

The events of World War II both traumatised and changed Belarus. The independent republic proclaimed in 1918 did not endure. However, Belarus secured its nationhood in the form of the Belarusian Soviet Socialist Republic (BSSR), which in 1945 became a charter member of the United Nations. As the relationship between the U.S. and the Soviet Union worsened during the late 1940s, representatives from the American administration (particularly those associated with UNRRA $^{6}$ ) came into contact with Belarusians. A new wave of post-war immigrants started to draw the attention of American policy makers to the mass of people in Europe known as displaced persons (among them Belarusians).

American international interests, namely perception of the Soviet Union as its main rival, went hand in hand with internal attempts of Belarusian post-war immigration to draw American attention to Belarus as a country under the Soviet yoke. Approximately 20,000 Belarusian displaced persons came to the United States after World War II (Hardzijenka 2009). By 1951, a number of Belarusian immigration organizations had actively been drawing the attention of the U.S. government to Belarus as a country, which lacked freedom within the Soviet Union. Post-war Belarusian immigration differed from the waves that preceded it, because now immigrants were nationally conscious (Hardzijenka 2009). Upon arrival, these immigrants started to lobby for recognition of the existence of the Belarusian state as national and ethnic entity and for its right for freedom and national self-determination. The Congressional Record mentions Belarusian participation among the delegates at the Congress of Independence Movements, held on 12-14 June 1950. The reports presented at the Congress call the Soviet Union 'the Giant on Clay Feet,' which 'is doomed to ultimate defeat and destruction. The very fact that it oppresses millions of alien peoples, breeds the germs of this destruction' (Congressional Record 1951, p. A530).

Congressman Charles J. Kersten's introduction to the House Concurrent Resolution 89 on 3 April 1951, and to the House Concurrent Resolution 94 on 11 April 1951, aimed to assist in the liberation of the Russian and non-Russian peoples of the Soviet Union from Communist enslavement and for the restoration of their basic human rights and freedoms. The Congressman's presentation drew many supportive responses from numerous Belarusian-American organizations:

6 The United Nations Relief and Rehabilitation Administration (UNRRA) began its work in 1943. It worked to provide services for the post-war refugees. 
Chicago, Ill., 4 July 1951. This resolution is a great step toward helping the Byelo-Russians obtain their independence. The White Russian American National Council most heartily thanks you. The name of Charles J. Kersten shall never leave the hearts of the ByeloRussian people. T. Lobatch, Secretary, White Russian American National Council. . .

Brooklyn, N.Y., 26 April 1951. The executive board and members of Byelo-Russian-American Association, in the U.S.A., Inc., extend their spontaneous and whole-hearted congratulations to you on your Concurrent Resolution 94, submitted to the House of Representatives on 17 April 1951. Unquestionable principles for which you stand have strengthened our hopes of early liberation of our people. We assure you that Byelo-Russian people will never forget your magnificent deed on its account. Nicholas Horoshko, Chairman, Byelo-RussianAmerican Assn., Inc. . .

Passaic, N.J., 8 May 1951. I appreciate your Concurrent Resolution No. 94 and wish for it the fulfilment. Rev. Nicholas Lapitzki, Chairman, Byelo Russian-American Relief Committee. . .

South River, N.J., 7 May 1951. Byelo Russian Congress Committee of America presents our cordial expression for your resolution. Dr. Nicholas Scors, President, Byelo Russian Congress Committee of America. .

New York, N.Y., 24 April 1951. On behalf of Russian scholars accept our heartfelt thanks for your resolution. Professor Stankevich, President, Byelo Russian Scientific Society (Congressional Record 1951, p. A5347).

In the second half of 1954, the U.S. Congress established a commission chaired by the same Congressman, Charles Kersten, to investigate acts of Communist aggression. The leaders of the Belarusian diaspora in the U.S. (N. Scors, ${ }^{7}$ N.

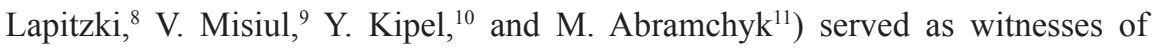
Communist persecution in Belarus and delivered their testimonies in person in New York and Munich (Mierlak, 1992). In 1955, the U.S. Congress published

\footnotetext{
7 Nikolas Scors was the first chairman (1951-1955) of the Belarusian Congress Committee of America.

8 Nicholas Lapitzki was the Right Reverend Protopresbyter of the Byelorussian Greek-Orthodox Church of St. Euphrosynia in South River, N.J.

9 Vasil Misiul was a member of the council of St.Cyril's of Turov in Brooklyn, N.Y.

${ }^{10}$ Yauhim Kipel was a member of the Belarusian Congress Committee of America, founder of the Union of Belarusian prisoners of Soviet labor camps.

${ }^{11}$ Mikalai Abramchyk was a President of the Council of the Belarusian National Republic (BNR), 1947-1970.
} 
a pamphlet 'Communist Takeover and Occupation of Byelorussia.' In addition, Belarusian immigrants started a campaign to promulgate their political ideas among U.S. legislators, mayors, and local officials. Undoubtedly, the activities of Belarusian migrants in the U.S. contributed to the acceptance of the view of the Soviet regime as an occupying regime and the BSSR as a captive nation. Eventually, Belarus appeared on a list of 22 nations that lost their independence due to Communist aggression in U.S. Public Law 86-90, which declared the third week of July as 'Captive Nations Week' ${ }^{12}$ President Dwight D. Eisenhower signed the Congressional resolution on captive nations week into law in 1959.

The Congressional Record also mentions the activities of the Byelorussian American Women's Association among 12 groups comprising the United Organizations of Women from Central and Eastern Europe. In 1968, the date set by UNESCO as the International Year of Human Rights, the members of the womens groups were organised in associations and prepared a memorandum as a reminder that 'freedom-loving nations must diligently strive toward protecting the right of people everywhere to live without fear of national, religious, or racial discrimination' (Congressional Record 1968, p. 11869). The memorandum was prepared for study at the first United Nations' International Conference on Human Rights in Teheran, Iran, in 1968.

Active petitioning by Belarusian migrants to U.S. Congress managed to clear the confusion of the name 'White Russia' with the White Russian movement which developed in 1918 when the Bolsheviks were busy establishing total power in Moscow. The Congressional Record provides the address of Congressman Michael A. Feighan, who spoke before the White Ruthenian-Byelorussian-Congress Committee of America at the Commodore Hotel in New York City on 28 March 1954 , on the occasion of the 36th anniversary of the Declaration of Independence of the Belarusian nation stating:

We should never confuse the cause of the white Ruthenian people with that of the political monarchist movement, known as the 'White Russians.' The white Ruthenian people have never supported Russian totalitarianism, whether under the czars or the Bolsheviks, but have always striven for their national independence (Congressional Record 1954, p. A2370).

Among many topics petitioned by Belarusian-Americans and Belarusian communities abroad was against the refusal by Voice of America (VOA), a U.S. government-funded international news outlet, to broadcast in Belarusian. The official excuse was 'budgetary restrictions' and that Radio Liberty already

${ }^{12}$ Captive Nations Week began in 1953. It aims at raising public awareness of the oppression of nations under the control of Communist and other non-democratic governments. 
broadcast in Belarusian (Kipel, 2017). The Belarusian community did not accept the excuse, and a struggle with the VOA continued for decades.

After 1959, the topic covered most in the Congressional Record is the observance of Belarusian Independence Day on March 25, 1918. Most of the speeches and proclamations dealing with Belarusian topics appear as remarks referencing Independence Day. For example, the Congressional Record contains a long, detailed letter about the 'genocidal policy of Soviet Russia in BSSR' from the Byelorussian Congress Committee of America and its president John Kosiak attached to one of the House Representative's speeches in 1971:

The Byelorussian Soviet Socialist Republic is not a Byelorussian State and was not created by the Byelorussian people. The Byelorussian Soviet Socialist Republic was created by the Russian Bolsheviks in 1919 in order to subvert the aspirations of the Byelorussian people, who had proclaimed their own Independent Bylorussian Democratic Republic in March 1918. ... The Soviet Russian regime in Byelorussia is carrying out a systematic Russification campaign (Congressional Record 1971, p. 7960).

The number of documents in support of Belarusian independence increased greatly on anniversaries. For example, for the 40th anniversary of Belarusian independence in 1958, the Congressional Record indicates the addresses of twelve congressmen from nine different states (Minnesota, Wisconsin, New Jersey, New York, Michigan, Massachusetts, California, Ohio, Illinois). The Senators from Illinois and Minnesota note details about the history of Belarusian independence and the importance to declare solidarity with the people of Belarus in hopes to get rid of Soviet oppression and restore the independence for Belarus (Congressional Record 1958, pp. 51976600). The Congressman from New Jersey, Peter W. Rodino, stated as follows:

The Free World admires the bravery and courage of the Byelorussian people. And on this anniversary date I rise to salute them and to join in the hope with my Byelorussian American friends that it will not be long before the stout-hearted people of Byelorussia will again enjoy independence and freedom and attain that ideal of free life within the family of democratic nations (Congressional Record 1958, p. 5333).

For the 50th anniversary, the number of speeches in U.S. Congress in support for Belarusian independence increased to 23. They represented ten different states (Michigan, Wisconsin, Virginia, Pennsylvania, New Jersey, Ohio, Minnesota, Alabama, New York, Illinois). In addition, Senators from Pennsylvania, Ohio, New York, and Illinois also praised the resistance of the Belarusian people and expressed hope for Belarusian independence (Congressional Record 1968, pp. 7523-8342). 
A notable fact is that Belarusian-Americans did not express any preference over the party affiliation of the congressmen giving speeches in support of Belarusian statehood. The main goal for Belarusian diaspora remianed to attract attention to Belarus. For example, for the $40^{\text {th }}$ anniversary of independence in 1958, out of four congressmen from New York, three represented the Democratic party, while out of two congressmen from New Jersey, both were Republicans. Similarly, in 1968, out of three congressmen from Ohio, two were Republican, while out of five congressmen from New Jersey, three were Democrats.

Belarusian priests received invitations to give opening payers in U.S. Congress almost every year on the anniversary of the proclamation of Belarusian independence throughout the 1960s, 1970s, and 1980s (Lapitzki, 2005). The Congressional Record mentions Reverend Archbishop Vasili of the Byelorussian Autocephalic Orthodox Church in New York, Vicar Bishop to Metropolitan Andrew and Primate of the Byelorussian Autocephalic Orthodox Church in the New York metropolitan area Iziaslav Brucky, Pastor of St.Cyril's of Turov the Reverend Russell Wojtenko in Brooklyn, Reverend Sviatoslaw Kous St. Cyril of Turov Byelorussian Orthodox Church Richmond Hill, New York, the Right Reverend Protopresbyter Nikolaj Lapitzki of the Byelorussian Greek-Orthodox Church of St.Euphrosynia in South River, New Jersey, and Byelorussian Autocephalic Orthodox Church Reverend Vasili Kendysh in Highland Park, New Jersey. The prayer commemorating the 50th anniversary of Belarus's proclamation of independence took place both in the House of Representatives and in the Senate. In 1971, while being invited to the Halls of the Congress, Reverend Nikolaj Lapitzki received recognition as 'a guiding spirit within his community of Byelorussian people in keeping their hopes alive for the resurrection of Byelorussian freedom and independence' (Congressional Record 1971, p. 7959).

Belarusian-Americans were also drawing attention to religious persecution in the BSSR. According to the Byelorussian-American Association, Eastern Orthodox, Roman Catholic as well as Belarusian Protestants were persecuted worse than in any other part of the Soviet Union. Among the reasons explaining ferocious religious persecutions in Belarus was that the Byelorussian national movement, which culminated with the proclamation of Byelorussian independence on 25 March 1918, 'called also for the establishment of an Independent Byelorussian Autocephalic Orthodox Church.' Another explanation offered by Belarusian immigrants was that 'Byelorussia is deemed "one of the dangerous western borders"' (Congressional Record 1980, p. 31022).

Recognition of Belarus as an independent state under Soviet rule stood out as a favourable theme for U.S. interests to gain advantage in the diplomatic manuvering of the Cold War. The Concurrent Resolution 58 on Diplomatic Representation of 
the Republics of the Ukraine and Byelorussia, introduced on February 9, 1953, by Congressman Lawrence Smith of Wisconsin advocated for the establishment of U.S. diplomatic representation in the capitals of Ukraine and Belarus. BelarusianAmericans recognised the significance and advantages of the Smith's resolution. Such deeds would be of enormous importance for the two oppressed nations and for U.S. policy, but they would also strengthen the bonds of alliance between the U.S., Ukraine and Byelorussia (Congressional Record 1953, p. A3857). In 1953, the Byelorussian Central Council supported the resolution by stating:

The Byelorussian people are suffering now in B.S.S.R. the worst national persecution, economic exploitation, sovietization, and russification its history has ever known. Therefore, the Concurrent Resolution No. 58 has especially great importance for the national liberation Byelorussian movement (Congressional Record 1953, p. A2495).

The death of Congressman Smith delayed the future of Concurrent Resolution No. 58. But the activities on the matter continued. Congressman Leonard Farbstein of New York in House Joint Resolution 355 called for U.S. diplomatic relations with the Republics of Ukraine and Byelorussia (Congressional Record 1959, p. A4481). However, the success of the Captive Nations Week, signed into law the same year, again delayed the development of diplomatic relations. Congressman Leonard Farbstein of New York advocated for the same issue in 1963 in House Joint Resolution 428 (Congressional Record 1963, p. 8606). It was followed by House Joint Resolutions 469, 476, 498, 508 in 1965 (Congressional Record 1965, pp. 10494-13433), the House Joint resolution 222 in 1967 (Congressional Record 1967, p. 1781) and 994 in 1971 (Congressional Record 1971, p. 44375), and Concurrent Resolution 382 in 1977 (Congressional Record 1977, p. 259). However, the strenuous relationship of the U.S. and the Soviet Union and their struggle for domination in the international arena delayed the progress of those resolutions in U.S. Congress. Meanwhile, the expulsion of nationalist China from the United Nations triggered a trail of declarations by various congressmen calling for the expulsion of Ukraine and Byelorussia from the United Nations. Such requests were supported by claims that both countries were ineligible for membership in 1945 and that 'neither the Ukraine nor Byelorussia has been sovereign since the Communist takeover in 1918; neither has diplomatic relations with any other nation in the world, nor does either of these provinces conduct foreign relations separate from those of the U.S.S.R. (Congressional Record 1971, p. 40261). The matter challenging the credentials of the delegations of the Ukrainian and the Byelorussian Soviet Socialist Republics was followed by the House Concurrent Resolution 408 in 1975 (Congressional Record 1975, p. 30435) and the House Resolution 448 
in 1984, (Congressional Record 1984, p. 735) and 383 in 1986, (Congressional Record 1986, p. 2528). Inconsistency in addressing the Belarusian question in U.S. Congress delayed establishment of diplomatic relations with Belarus till 1991 after the collapse of the Soviet Union.

Nevertheless, it is undeniable that the work of Belarusian-Americans in the United States, attracting the attention of U.S. administration to the situation in Belarus under the Soviet rule, long before the 1990s, managed to serve as a domestic influence shaping American policy towards Belarus by promoting the idea of Belarus as a separate country deserving national self-determination and independence.

The number of congressional speeches, however, significantly decreased towards the 70th anniversary of Belarusian independence in 1988 (see Figure 1). The reduction can be explained by the profound changes in economic practice, internal affairs and international relations through perestroika ('restructuring') and glasnost ('openness') introduced by Mikhail S. Gorbachev after becoming general secretary of the Communist Party of the Soviet Union in March 1985. The priority of the activities of the Belarusian diaspora turned from Washington D.C. directly towards Belarus, because it became easier to develop relations with Belarus at that time.

In 1991, the Republic of Belarus became an independent state, however, contact with Congressional Washington continued. After the declaration of Belarusian sovereignty on July 27, 1990, and Belarusian independence on August 25, 1991,

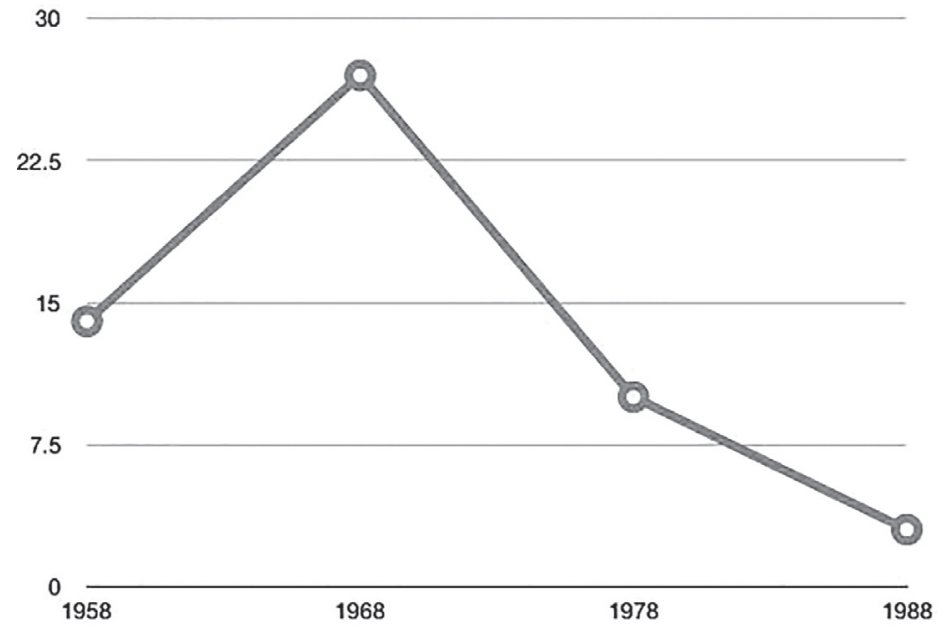

FIGURE 1: Number of U.S. politicians making speeches in U.S. Congress in support of Belarusian independence declared on March 25, 1918 
the speeches of congressmen devoted to Belarusian independence in 1918 became enthusiastic, having in mind the democratic development of the new independent republic. New Jersey Congressman Frank Pallone Jr. stated in his speech in 1992: "The small nation stands at a historic crossroads. It is my hope and my belief that Byelorussia will meet with success. I wish the Byelorussian people all the best on the anniversary of their proclamation of independence" (Congressional Record 1992, p. E812). In 1994, Belarus received its second presidential visit from the United States. ${ }^{13}$ This act by President Clinton aimed to pay respect to Belarus gaining its nuclear-weapon-free-status on its own initiative. To assist Belarus in undertaking serious economic reform, President Clinton informed Chairman Šuškievich of a new financing package of $\$ 10$ million in technical assistance for Belarus. President Clinton and Chairman Šuškievich signed the Bilateral Investment Treaty, agreed to establish an American Business Center in Minsk, a Regional Enterprise Fund, and a bilateral Business Development Committee 'to help identify and resolve problems that impede business expansion and to seek ways to develop new business opportunities' (Congressional Record 1994, p. 3126).

At the same time the removal of Šuškievich by Parliament on January 26, 1994, two weeks after he received strong backing from President Clinton, raised concerns for U.S. politicians that the reform process in Belarus might be slowing down. The ouster of a non-Communist reformer left Belarus in the hands of the same party bureaucrats who ran it before the collapse of the Soviet Union in December 1991. Congressman Steny H. Hoyer of Maryland expressed his concerns for Belarus's future before the presidential elections of 1994 :

I have to note with concern that, according to Russian and Belarusian sources, the Belarusian Government appears to be launching a campaign to restrict media outlets... as Belarus moves toward its first post-Soviet Presidential elections, the Government should ensure that the media remain free to publish the entire range of opinions in the country (Congressional Record 1994, p. 12762).

The first national presidential elections in Belarus since the collapse of the Soviet Union were held on June 23, 1994, with a second round on July 10. The election of Aliaksandr Lukashenka as the first president the Republic of Belarus marked the beginning of the end of the reform period.

\section{Conclusion}

Migration has been one of the major forces shaping the world and serving as a major factor in world history. In many cases, immigrants move to another country

\footnotetext{
${ }^{13}$ Richard Nixon made a visit to Belarus in 1974.
} 
in search of more positive futures. While some migrants consider relocation to a new country as a permanent move, others often plan to settle only temporarily in their new, host country. Many individuals do not forget their home country and continue to support family members and advocate for a better future for their homeland. This paper attempted to show how post-war immigrants from Belarus were fighting for the recognition of their home country as an independent nation under Soviet oppression.

The period from 1873, when the Congressional Record was first published, until the 103rd Congress in 1994 shows that U.S. officials directed their attention towards Belarus in connection with the Belarusian political status on the international arena and diaspora's lobbying for the recognition of Belarus as a separate nation. By lacking real independence, Belarus was represented as the 'North-Western Territory' within the Russian Empire and later as a part of the Soviet Union. Even though Belarus was able to declare its independence in 1918, which became the basis for the establishment of the BSSR, its status as one of the republics, comprising the Soviet Union, did not attract enough attention from U.S. Congress. Only in the early 1950s, when post-war immigrants became involved in actively portraying Belarus from the perspective of a nationality oppressed by the Soviet Union, did the American government then start to pay more attention to Belarus and portray it as an oppressed nation of the Soviet Union.

There is still much academic research to be done. Other U.S. governmental documents may also have covered Belarus. Learning about the ways that migrants shaped American politicians' perception of their countries of origin will enhance our understanding of the role of migrants for foreign policy, and transform both our knowledge and and insight into the development of government policies.

\section{Acknowledgments}

The author wishes to thank Dr. Vitaut Kipel for his inspiration, insightful comments and suggestions for this essay. 


\section{References}

Congressional Record 1882. 47th Congress, Vol.13, Sess. 1, p. 653.

Congressional Record 1918. 65th Congress, Vol.56, Sess. 2, p. 9624.

Congressional Record 1920. 66th Congress, Vol.59, Sess. 2, p. 7556.

Congressional Record 1932. 72nd Congress, Vol.76, Sess. 1, p. 12536.

Congressional Record 1939. 76th Congress, Vol.85, Sess. 2, p. 204.

Congressional Record 1942. 77th Congress, Vol.88, Sess. 2, p. 2849.

Congressional Record 1943. 78th Congress, Vol.89, Sess. 1, p. 2228.

Congressional Record 1951. 82nd Congress, Vol.97, Sess. 1, pp. A530, A5347.

Congressional Record 1953. 83rd Congress, Vol.99, Sess. 1, pp. A2495, A3857.

Congressional Record 1954. 83rd Congress, Vol.100, Sess. 2, p. A2370.

Congressional Record 1958. 85th Congress, Vol.104, Sess. 2, pp. 5197, 53225336, 5515-5519, 5869, 6600 .

Congressional Record 1959. 86th Congress, Vol.105, Sess. 1, p. A4481.

Congressional Record 1963. 88th Congress, Vol.109, Sess. 1, p. 8606.

Congressional Record 1965. 89th Congress, Vol. 111, Sess. 1, 13 May, pp. 10494, 10922, 12477, 13433.

Congressional Record 1967. 90th Congress, Vol. 113, Sess. 1, p. 1781.

Congressional Record 1968. 90th Congress, Vol. 114, Sess. 2, pp.11869, 74757523, 7764, 8200, 8342 .

Congressional Record 1971. 92nd Congress, Vol. 117, Sess. 1, pp. 7960, 40261, 44375.

Congressional Record 1975. 94th Congress, Vol. 121, Sess. 1, p. 30435.

Congressional Record 1977. 95th Congress, Vol. 123, Sess. 1, p. 259.

Congressional Record 1980. 96th Congress, Vol. 126, Sess. 2, p. 31022.

Congressional Record 1984. 98th Congress, Vol. 130, Sess. 2, p. 735.

Congressional Record 1986. 99th Congress, Vol. 132, Sess. 2, p. 2528.

Congressional Record 1992. 102nd Congress, Vol. 138, Sess. 2, p. E817.

Congressional Record 1994. 103rd Congress, Vol. 140, Sess. 2, pp. 3126, 12762.

Hardzijenka, A. 2009. Belarusian Congressional Committee of America (BCCA). World Association of Belarusians: Baćkaǔščyna. 
Hardzijenka, N. 2004. Belarusians in Australia. World Association of Belarusians: Baćkaǔščyna.

Kipel, V. 1993. Belarusians in the U.S. Belarus.

Kipel, V. 2017. Belarusians in the U.S. Minsk, 'Knihazbor'.

Klier, J. 2002. Christians and Jews and the 'Dialogue of Violence' in Late Imperial Russia, in Religious Violence between Christians and Jews: Medieval Roots, Modern Perspectives. Palgrave Publishers Ltd., pp. 157-170.

Koval, O. 2010. Economic-Based Emigration of Belarusians to the United States (1918-1939), Journal of International Law and International Relations, pp. 58-62.

Lapitzki, N. 2005. In the Service of God and Belarus. New York: BINIM.

Leblang, D. 2010. Familiarity Breeds Investment: Diaspora Networks and International Investment, American Political Science Review, Vol. 104, No. 3, pp. 584-600.

Mierlak, K. 1992. Activity of Constant Mierlak in the Emigration: Penetrating and Practical Approach. New York: Polacak.

Rudling, P. 2012. Nationalism in Modern Belarus, Baltic Rim Economies Expert Articles, p. 133.

Shain, Y. 1994. Ethnic Diasporas and US Foreign Policy, Political Science Quarterly, Vol. 109, No. 5, pp. 811-847.

Shain, Y. 2003. Diasporas and International Relations Theory, International Organization, Vol. 57, No. 3, pp. 449-479. 